\title{
Historical Events in Symbols and the Freedom of Expression: The Contemporary Constitutional Debate in Croatia
}

\author{
ĐORĐE GARDAŠEVIĆ \\ Law Faculty, University of Zagreb
}

\begin{abstract}
Summary
In the last few years, the Croatian Constitutional Court delivered several important decisions that significantly shaped interpretative approaches to constitutional guarantee on the freedom of expression in the specific context of the public use of some symbols with contested meanings. Such developments undoubtedly deserve attention, especially in terms of particular tools that the Court used in defining limits to free speech. The primary focus of this article is directed to the issue of whether the use of contested symbols in public may be covered by constitutional free expression guarantees, and be therefore treated as the case of balancing process between them and some opposed interests, or it should be subjected to stricter prohibitions, including their complete ban. For those purposes, I am first presenting the relevant case-law of the Croatian Constitutional Court and then the cases already decided in a similar fashion by the European Court for Human Rights. In the final part I am presenting some personal views on how a further structured approach to constitutional interpretation in cases involving the use of contested symbols with historical meanings could possibly be construed in the Croatian context.

Keywords: Freedom of Expression, Free Speech, Contested Symbols, Disputed Insignia, Constitutional Adjudication
\end{abstract}

\section{Introduction}

Freedom of expression has been one of the principal guarantees of the modern Croatian constitutional order ever since the adoption of the Constitution of $1990 .{ }^{1}$ Article

1 The article was partially presented during the international symposium Hate Speech, Symbols and Memories held at the Faculty of Political Sciences, University of Zagreb on June $6^{\text {th }}$. It should also be noted that this article was written as a part of the research project "The New Croatian Legal System" (Law Faculty, University of Zagreb). 
38 of the said document in its present form thus combines all relevant elements of the concept. The general guarantee is thus strengthened with some specific elements: freedom of the press and other media of communication; freedom of speech and public expression; free establishment of all institutions of public communication; prohibition of censorship; freedom of reporting and free access to information; and right to correction to anyone whose constitutional and legal rights have been violated by public information. ${ }^{2}$ At the same time, like in the case of most other constitutional rights and freedoms, possible limitations to freedom of expression are subject to general criteria formulated in Article 16 of the Constitution. Those specifically require: that restrictions are prescribed by law; that they pursue a legitimate aim (protection of freedoms and rights of others, of legal order, public morality and health); and that they conform to the principle of proportionality. ${ }^{3}$ But most importantly, freedom of expression has also, since 1990, been subject to additional and very strict constitutional limitations. Article 39 of the Constitution thus states that "any call for or incitement to war, or resort to violence, national, racial or religious hatred, or any form of intolerance shall be prohibited and punishable by law".

Interestingly though, prohibition of "hate speech" and related categories mentioned in Article 39 of the Croatian Constitution has not, until quite recently, been subject to the Constitutional Court's scrutiny (Gardašević, 2016: 160-161). In 2016 and 2017, however, the situation strikingly changed when the Constitutional Court delivered four decisions which started to shed some light on the meaning of constitutional prescriptions addressing the use of certain slogans or symbols which in the Croatian public sphere have for a long time been contested. ${ }^{4}$

Undoubtedly, those cases deserve particular attention. Accordingly, my attempts in this paper are focused on presenting the major features of the Croatian constitutional debate, seen through the lenses of the Constitutional Court's caselaw, as it refers to the freedom of expression in the specific context of the use of

2 For the text of the Constitution of the Republic of Croatia in English, see: https://www.constituteproject.org/constitution/Croatia_2013?lang=en, October $12^{\text {th }} 2018$.

${ }^{3}$ Article 17 of the Croatian Constitution prescribes only a few constitutional rights that may not be restricted even in the case of an immediate threat to the State: the right to life, prohibition of torture, cruel or degrading treatment or punishment, guarantees on the legal definitions of penal offenses and punishments, freedom of thought, conscience and religion. With the exception of those absolute rights, all other constitutional rights and freedoms are therefore relative ones and subject to possible limitations according to Article 16 of the Constitution.

${ }^{4}$ To be sure, I must stress already here that, apart from one dissenting opinion, the Court's majority in the cases under examination actually did not expressly invoke the prescriptions of Article 39 of the Croatian Constitution, but rather reviewed the cases from several other constitutional aspects that I will try to present further. Still, those cases bear crucial relevance for describing limits to free expression in the overall Croatian context, especially in terms of the discourses on limits to "prohibited expression" as it pertains itself to the use of certain symbols. 
contested symbols. To that end, I emphasize, my paper is strictly focused on legal aspects of relevant cases or, more precisely, on their constitutional context. ${ }^{5}$

The highlight of my attempt is principally linked to the specific issue of whether the use of contested symbols in public may be covered by constitutional free expression guarantees, and be therefore treated as the case of balancing process between them and some opposed interests, or it should be subjected to stricter prohibitions, including their complete ban. This specific theme is by no means new in constitutional law. As I will show more precisely later, the proposed division (i.e. limitations of rights $\mathrm{v}$. general exclusion of legal protection for certain acts) actually reflects in important ways two major approaches commonly used by the European Court of Human Rights in cases involving the "hate speech" problem. Generally, thus, this Court in such cases applies either the "balancing" method as it stems from the limitation clause of Article 10 par. 2 of the European Convention on Human Rights or the "exclusion" method that is contained in its Article 17 (Prohibition of Abuse of Rights).

This paper is divided in three parts. In the following chapter (II. Facts of the Case: Croatian Constitutional Justice in Practice) I am presenting developments in the case-law of the Croatian Constitutional Court relevant for the issues I described. Proper understanding of this case-law is indispensable for gaining a somewhat complete and clear picture on how the highest constitutional authority in Croatia construed its views on the delicate relationship between the free speech guarantees and the public uses of several symbols in the Croatian setting broadly understood as having contested meanings. In the third part (III. The Strasbourg Signals Reconsidered - The Balancing Method or an Outright Ban?), I am reviewing the cases of the European Court of Human Rights relevant for problems similar to those which have occurred in the Croatian context. This part is principally aiming to draw some comparisons to the case-law of the Strasbourg tribunal in terms of application of either Article 10 par. 2 or Article 17 of the European Convention. In the final part (IV. Conclusion), I will give some personal remarks on how a further structured approach to constitutional interpretation in cases involving the use of contested symbols with historical meanings could possibly be construed.

${ }^{5}$ For recent attempts to solve the problem of the public use of various contested symbols in the Croatian settings, see also: Dialogue Document: Postulates and Recommendations on Specific Normative Regulation of Symbols, Emblems and other Insignia of Totalitarian Regimes and Movements, the Council for Dealing with the Consequences of Undemocratic Regimes, February $28^{\text {th }} 2018$ (Zagreb). The English version at: https://vlada.gov.hr/UserDocsImages//Vijesti/2018/05\%20svibanj/5\%20svibnja//DOKUMENT\%20DIJALOGA\%20ENG.pdf, October $17^{\text {th }}$ 2018. The Croatian version (including the separate opinions) at: https:/vlada.gov.hr/istaknuteteme/dokument-dijaloga-temeljna-polazista-i-preporuke-o-posebnom-normativnom-uredjenjusimbola-znakovlja-i-drugih-obiljezja/23424, October $17^{\text {th }} 2018$. 


\section{Facts of the Case: Croatian Constitutional Justice in Practice}

As I already indicated in the introduction, the case-law of the Croatian Constitutional Court relevant for the issues at stake here includes, at least, four decisions.

In the Miljak case, ${ }^{6}$ the Court upheld rulings of lower courts in punishing the applicant who organized a public commemoration in favor of a well-known World War II officer. During the event, the applicant also held a speech in which he described the creation of the Independent State of Croatia, the wartime career of the said officer and his unit. Moreover, after the speech, he shouted the slogan "Bog i Hrvati, za dom" (God and Croats, for Home). This was responded to by another person from the crowd who shouted "Spremni" (Ready) and raised her hand in the air, thus imitating the Nazi salute. Lower courts found that this constituted a breach of public order and peace and thus was punishable as a misdemeanor because the applicant, by his speech and shout, was inciting an organized group to behavior producing intolerance towards others.

Technically, the Constitutional Court reviewed the case from the aspect of the constitutional guarantee of fair trial, ${ }^{7}$ but in the crucial part of the Decision, it pointed to and accepted the findings of the second instance court that are directly relevant for the problem of free speech. In that particular respect, the second instance stated the following: "It clearly follows from the provisions of the Constitution that the republic of Croatia is not founded on historical inheritance of the Independent State of Croatia, whose prominent member was Jure Francetić, and freedoms and rights of the applicants as members of the political party Hrvatska čista stranka prava ("The Croatian Pure Party of Rights") in public expression of personal opinion in the concrete case are restricted by the Law on Misdemeanors Against Public Order and Peace, by its Article 5, and in accordance with Article 16 of the Constitution, in order to protect freedoms and rights of others and the legal order. In the concrete case the restrictions of rights of the applicants are directed towards a legitimate aim and they are proportionate... because the applicants were putting forward unacceptable political messages on which the Republic of Croatia, as an independent, sovereign and democratic state, is not based." ${ }^{8}$ In addition, the second instance court rejected the applicant's argument that he was not disturbing the public because nobody else apart from those participating at the commemoration was

${ }^{6}$ Decision of the Constitutional Court of the Republic of Croatia, U-III-1296/2016, May $25^{\text {th }} 2016$.

7 The reason for this was that the applicant himself based his constitutional complaint to the Constitutional Court on Articles 26 and 29 of the Constitution, and not on Article 38. Therefore, the Court was bound by this fact from the technical point of view. Nevertheless, as I explain in the main text, the issue of free speech was addressed as well, although in an indirect way.

${ }^{8}$ Decision of the Constitutional Court of the Republic of Croatia, U-III-1296/2016, May $25^{\text {th }}$ 2016, par. 4 . 
present. Having determined instead that the commemoration was actually organized on an open town square, therefore on an unlimitedly open public space that is permanently accessible to an unlimited number of persons, the court concluded that it was not required to specifically determine the presence of other people. ${ }^{9}$

Soon after this Decision, in the Hajduković case the Court dealt with the constitutional complaint of a person who claimed that there was a breach of his freedom and privacy of correspondence in a situation where the prison authorities banned him from sending several private letters. Those letters either contained the "Za dom spremni" (For the homeland ready) slogan or were specified to be sent to an address in the "Independent State of Croatia" or included insult or slander to the personnel working in the prison. The second instance court qualified the bans as pursuing security reasons, which included prohibitions of insult and slander as well as presentation of forbidden symbols. The legal grounds for security reasons were located in the Law on the Execution of the Penalty of Imprisonment and in the Law on Misdemeanors. The Constitutional Court affirmed the decision for the same reason albeit in a rather short passage in which it only briefly argued that privacy of correspondence is generally subject to restrictions in public interest and in accordance with the principle of proportionality. ${ }^{10}$

The "balancing" approach can clearly be observed in the third, Šimunić case ${ }^{11}$ where it was decided that lower courts did not breach the free speech guarantees when punishing a player who, shortly after the end of a football match, took up a microphone and four times publicly shouted the "Za dom" slogan. This was responded to from some within the stadium audience with "Spremni" and was heard both by those at the stadium and by those following the media covering the event. Consequently, the first instance court qualified the applicant's conduct as misdemeanor because, and taking into account the place, the way he did it and the communication he had with the audience, the message he thus conveyed was in its content inciting to hate on account of racial, national, regional or religious origin. The court found that the shout used by the applicant, as well as the response to it, symbolized the official salute in the totalitarian regime of the Independent State of Croatia and that as such the salute represented manifestation of racist ideology, contempt for other people on account of their religious and ethnic identity and trivialization of the victims of crimes against humanity. The same court also stressed that the Republic of Croatia, among other things, signed the United Nations Convention on the Elimination of All

\section{${ }^{9}$ Ibid.}

${ }^{10}$ This time, however, two judges of the Court wrote their joint separate opinion. See: Decision of the Constitutional Court of the Republic of Croatia, U-III-5226/2013, October $18^{\text {th }} 2016$. ${ }^{11}$ Decision of the Constitutional Court of the Republic of Croatia, U-III-2588/2016, November $8^{\text {th }} 2016$. In this case there was one separate opinion. 
Forms of Racial Discrimination and pointed that the same standing was expressed in the Sugg and Dobbs v. Sweden case. ${ }^{12}$

The appellate court reaffirmed the conviction and, like the first instance, paid special attention to the problem of qualification of the contested salute. The applicant, backed up by an expert opinion, tried to argue that throughout history the salute has had multiple meanings. However, the court firmly emphasized that, despite other contexts, it was undisputable that the slogan was an official salute during the totalitarian regime of the Independent State of Croatia, that it was used on all official documents of that state and that the movement which led that regime itself emerged from fascism, which was among other things based on racism. The conclusion was therefore that the slogan symbolized hatred towards others because of their religious and ethnic belonging, manifestation of racist ideology, as well as underestimation of victims of crimes against humanity. The second instance court also referred to the element of the public space and pointed that the event was broadcasted through electronic media and that the applicant's hate speech was accessible to an unlimited number of spectators. ${ }^{13}$

The Constitutional Court accepted all the findings of the lower courts and rejected the applicant's constitutional complaint. This time, however, its reasoning was a bit more substantial than in the Miljak case. The Court opened its argument regarding the freedom of expression claim by stressing that constitutionally protected freedoms of opinion and expression were not absolute but rather subject to limitations prescribed by the Constitution and law and said that every particular case ought to be seen in terms of all relevant circumstances. This, furthermore, would include not only the content of contested statements, but also the context in which they were made public. And even more specifically, the Court pointed that any serious evaluation of such cases must take into account whether measures limiting freedom of expression were proportional to a legitimate aim thus sought and whether the interference was "necessary in a democratic society". The principal source of inspiration was found in the relevant case-law of the European Court of Human Rights dealing with restriction of the freedom of expression, namely the case of Guja v. Moldova. ${ }^{14}$

12 Ibid., par. 3. Sugg and Dobbs v. Sweden, the European Court of Human Rights (2001). For the case-law of the European Court of Human Rights, generally see the HUDOC database, available at: https://hudoc.echr.coe.int/eng\#\{\%22documentcollectionid2\%22:[\%22GRANDCHAM BER\%22,\%22CHAMBER\%22]\}, October $12^{\text {th }} 2018$.

${ }^{13}$ Decision of the Constitutional Court of the Republic of Croatia, U-III-2588/2016, November $8^{\text {th }} 2016$, par. 4 .

14 In the relevant part of that particular judgment the European Court stated:

"(i) Freedom of expression constitutes one of the essential foundations of a democratic society and one of the basic conditions for its progress and for each individual's self-fulfillment. Subject 
Applying those standards to the actual case, the Constitutional Court confirmed that the applicant was convicted on basis of the law ${ }^{15}$ and that the conviction represented an interference into his freedom of expression. At the same time, however, the legitimate aim of punishing conduct by which hatred on account of racial or other belonging was expressed or incited was found to be located in protection of the dignity of others ${ }^{16}$ as well as in basic values of a democratic society. The Court concluded by stressing that freedom of expression carried with it also responsibilities and obligations and that the punishment of the applicant, taking into account all the circumstances of the concrete case, was not an excessive intrusion into his freedom. ${ }^{17}$

to paragraph 2 of Article 10 (of the European Convention on Human Rights - note: Đ. G.), it is applicable not only to 'information' or 'ideas' that are favorably received or regarded as inoffensive or as a matter of indifference, but also to those that offend, shock or disturb. Such are the demands of pluralism, tolerance and broadmindedness without which there is no 'democratic society'. As set forth in Article 10, this freedom is subject to exceptions, which... must, however, be construed strictly, and the need for any restrictions must be established convincingly...

(ii) The adjective 'necessary', within the meaning of Article 10 paragraph 2, implies the existence of a 'pressing social need'. The Contracting States have a certain margin of appreciation in assessing whether such a need exists, but it goes hand in hand with European supervision, embracing both the legislation and the decisions applying it, even those given by an independent court. The Court is therefore empowered to give the final ruling on whether a 'restriction' is reconcilable with freedom of expression as protected by Article 10 .

(iii) The Court's task, in exercising its supervisory jurisdiction, is not to take the place of the competent national authorities but rather to review under Article 10 the decisions they delivered pursuant to their power of appreciation. This does not mean that the supervision is limited to ascertaining whether the respondent State exercised its discretion reasonably, carefully and in good faith; what the Court has to do is to look at the interference complained of in the light of the case as a whole and determine whether it was 'proportionate to the legitimate aim pursued' and whether the reasons adduced by the national authorities to justify it are 'relevant and sufficient'... In doing so, the Court has to satisfy itself that the national authorities applied standards which were in conformity with the principles embodied in Article 10 and, moreover, that they relied on an acceptable assessment of the relevant facts...". Guja v. Moldova, the European Court of Human Rights (2008), par. 69. The European Court of Human Rights in this case also pointed to other relevant cases decided by it before: Jersild v. Denmark (1994); Hertel v. Switzerland (1998); and Steel and Morris v. the United Kingdom (2005).

${ }^{15}$ Law on the Prevention of Disorder at Sport Competitions.

${ }^{16}$ It is worth noticing here the similar approach towards the protection of dignity, as a legitimate basis for restriction, which is present in the German law. In that context H. Rose specifies that in the German federal Criminal Code "the general prohibition of hate speech does not require a motive to discriminate on racial, ethnic, or other grounds, instead requiring only assaulting the dignity of or inciting hatred or arbitrary measures against 'segments of the population"' (Rose, 2014: 323). ${ }^{17}$ For the arguments of the Constitutional Court in reference to Article 38 (freedom of expression) in this case, see: Decision of the Constitutional Court of the Republic of Croatia, 
In October 2017 the Constitutional Court delivered the last decision I would like to present here. ${ }^{18}$ This time, it dealt with the decision of a local body by which one of the streets in a municipality was named " 10 . travnja" ("April $10^{\text {th" }}$ ). The Court's reasoning, in the context interesting here, started with determining that, in absence of any other proofs to the contrary, the contested name of the street could only be linked to the date of April $10^{\text {th }} 1941$, as the date of the establishment of the Independent State of Croatia. ${ }^{19}$ Following this, the Court then proceeded to introduce the central element upon which it would construe its reasoning, namely the element of so-called "well-known historical truths". Quoting the European Court of Human Rights from the Ždanoka v. Latvia case,,$^{20}$ it firstly said: “... the Court will abstain, as far as possible, from pronouncing on matters of purely historical fact, which do not come within its jurisdiction; however, it may accept certain wellknown historical truths and base its reasoning on them." ${ }^{21}$ From that general point, the Constitutional Court turned to more specific explanation of the concept, as it was revealed in the Garaudy v. France case, ${ }^{22}$ and stressed the following: “... denying the reality of clearly established historical facts, such as the Holocaust... does not constitute historical research akin to a quest for the truth. Having in mind that the Holocaust belongs to the category of clearly established historical facts, any negation or revision of it represents an abuse of the rights in the sense of Article 17 of the European Convention for the Protection of Human Rights and Fundamental Freedoms. In other words, any negation or revision of the Holocaust is contrary to the fundamental values of the Convention and therefore it cannot be under its

U-III-2588/2016, November $8^{\text {th }} 2016$, par. 9-12. In that sense, M. Oetheimer notes that in Article 10 cases the European Court applies the "closest scrutiny" test and clarifies the following: "Once the legality and the legitimacy of the interference in the exercise of freedom of expression have been confirmed, the judges review the content of the speech within the framework the so-called necessity-test. In other words, the Court will assess whether the free speech limitation was necessary in a democratic society and whether it was proportionate to the legitimate aim pursued. In addition, the Court refers to a number of facts, which have an influence on the context within which the speech has been produced" (Oetheimer, 2009). It seems that the substantive part of the relevant "content" and "context" fact-finding in the Šimunic case, from the point of view of the required elements of analysis, was already done by the lower courts and not by the Constitutional Court itself.

18 Decision of the Constitutional Court of the Republic of Croatia, U-II-6111/2013, October $10^{\text {th }} 2017$.

19 Ibid., par. 16.

20 Ždanoka v. Latvia, the European Court of Human Rights (2006).

${ }^{21}$ Decision of the Constitutional Court of the Republic of Croatia, U-II-6111/2013, October $10^{\text {th }} 2017$, par. 17 .

${ }^{22}$ Garaudy v. France, the European Court of Human Rights (2006). 
protection." ${ }^{23}$ Turning then to the facts of the case at hand, the Court stated: "Starting with what was already said, neither the Constitution nor the Convention can provide any protection to the celebration of April $10^{\text {th }} 1941$, the date of the establishment of the Independent State of Croatia, in any way, including the cases in which names of streets and squares are given in memory of that date. In fact, the 'well-known historical truth' is that the Independent State of Croatia was a Nazi and a fascist creation and as such it represented the absolute negation of legitimate aspirations of the Croatian people to found its own state, as well as grave historical abuse of such aspirations. Therefore, according to the Preamble of the Constitution, the Republic of Croatia is not a successor to the Independent State of Croatia on any basis." ${ }^{24}$ In a dictum the Court strongly emphasized that its constitutional standings were not merely related to names of streets, settlements, symbols and alike, but that they also represented its general standings on the character of the Independent State of Croatia, seen as negation of basic values of the constitutional order of the Republic of Croatia. ${ }^{25}$

But the most notable part of the Court's reasoning was presented in its view of the overall interpretative approach to the Constitution itself. More precisely, the Court stressed that the Constitution was not a value-neutral document, but rather that it affirmed Croatia as a democracy established upon the rule of law and protection of human rights and freedoms and that this was the only political model which the Constitution took into account and which it endorsed. From that point, in the Court's view, human rights and rule of law are in the context of the Constitution primarily set up to express a moral commitment to objective principles of a liberal democracy. ${ }^{26}$ Moreover, the Court continued, the Constitution is in itself based upon some structural principles, among which and together with the rule of law one must also find principles of freedoms, equality in general and national equality, peacemaking and respect for human rights. In addition, abrogation or revision of any of those structural principles would directly interfere with the very structure and essence of the Croatian state. ${ }^{27}$

23 Decision of the Constitutional Court of the Republic of Croatia, U-II-6111/2013, October $10^{\text {th }} 2017$, par. 17.1. For a critical view on the application of the "clearly established historical facts" concept, asking "to what extent will the (European - note: Đ. G.) Court expand the list of 'clearly established historical facts', the negation or downplaying of which can be excluded from the ambit of protection under Article 10?", see Arai, 2014: 624.

${ }^{24}$ Decision of the Constitutional Court of the Republic of Croatia, U-II-6111/2013, October $10^{\text {th }} 2017$, par. 18 .

25 Ibid.

26 Ibid., par. 19.

27 Ibid., par. 19.1. In a similar sense, E. Kulenović is arguing that the strategy of regulation of hate speech construed upon the possible concern for "erosion of basic political and social values" is "based on the idea that hate speech represents an attack to fundamental political and so- 
Consequently, the Court concluded that the rule prescribed in Article 17 of the European Convention was applicable in the Croatian constitutional scheme as well and that nothing in the constitutional order could be interpreted as a right of anyone to undertake a certain activity or carry out any act that would be directed to annulling any right or freedom guaranteed by the Constitution. In conclusion, thus, the Court said that the decision of a municipality at stake in this case was in direct collision with the rule of law principle, that it threatened the identity of the Croatian constitutional state to the level that could not be tolerated and that consequently it had to be annulled precisely because of the protection of that constitutional identity. ${ }^{28}$

Although it may be somewhat surprising that cases involving the public use of contested symbols (or disputed insignia) have only recently reached the highest constitutional authority in Croatia, it is a fact that the Croatian Constitutional Court in the last two years did give some concrete answers to the problems it was called to solve. Undoubtedly, the instructions of the Court bear a quality of constitutional precedents that, unless overruled, ought to be taken into account in future cases and analyses. ${ }^{29} \mathrm{I}$ will now try to summarize the main points that derive from the caselaw of the Croatian Constitutional Court.

cial values of constitutional democracies" and that it is "possible to limit the freedom of expression when it is about public speech by which fundamental values on which democratic political community is based are rejected" (Kulenović, 2016: 44). In specific reference to the Croatian Constitutional Court's standings that Constitution is not value-neutral but rather a document which shows commitment to the rule of law and protection of human rights and freedoms which in turn reveal moral commitment to objective principles of a liberal democracy, I find very inspiring the thoughts of J. Waldron in his discourse on a "well-ordered society" and the "appearances" that society is reflecting in public. In that sense, Waldron is saying this: "The question I have asked - what does a well-ordered society look like? - is not a coy way of asking what makes a society well-ordered, or what a well-ordered society is like. I am interested in how things literally look; I'm interested in the visible environment. How important is the look of things in a well-ordered society? Is it unimportant, compared to how things actually are? Or is it an important part of how things actually are? And if it is an important part of how things are, what in particular should we be looking for? The colorful, unruly diversity of a free market of ideas? Or the absence of visible features that are at odds with the fundamental commitment to justice with which a well-ordered society is supposed to be imbued?" (Waldron, 2012: 68).

${ }^{28}$ Decision of the Constitutional Court of the Republic of Croatia, U-II-6111/2013, October $10^{\text {th }}$ 2017, par. 20-21. This time however, just like in the above-described Šimunić case, judge M. Šumanović presented his own dissenting opinion. I leave further evaluation of the dissents mentioned in the Hajduković, Šimunić and April $10^{\text {th }}$ Street cases for some future occasion.

${ }^{29}$ Technically, one of the significant differences between the four examples I have described above is that in the first three cases the Court was actually resolving constitutional complaints of the applicants, whereas in the April $10^{\text {th }}$ Street case it was dealing with the constitutionality of a locally enacted general act. However, in the light of relevant provisions of the Constitutional 
As to the application of the "balancing" of competing interests method (freedom of expression against other constitutionally protected values) it may be noted that in the early cases the Court was only indirectly addressing the issue of expression, by principally confirming the standings of the lower courts. ${ }^{30}$ Quite broader and rather direct interpretation and application of the balancing approach may, however, be seen in the Šimunić case. Apart from that, a more thorough reading of the case-law reveals some other important points as well.

Firstly, in all four cases the Court was clearly dealing with the use of symbols which seem to share a certain historical or contextual background. In that sense, there is no straightforward answer to the question whether the pronouncements of the Court could directly be used in cases involving the use of other symbols. ${ }^{31} \mathrm{Se}-$ condly, as the Hajduković case shows, the presentation of some symbols may be restricted even in private correspondence of the applicant, although in certain specific instances such as the prison environment. The required conditions thereof are that the use is subject to the proportionality principle and that it interferes with some legitimate public interests, such as security reasons, which themselves are prescribed

Act of the Constitutional Court of the Republic of Croatia, the standings of the Court in all four cases, unless overruled by the same instance, must be seen as general prescriptions to be followed in all future cases, whether they are triggered by new individual complaints or by motions for review of constitutionality of general legal regulations. In that sense, the Constitutional Act of the Constitutional Court of the Republic of Croatia in its Article 31 par. 1. prescribes that "The decisions and the rulings of the Constitutional Court are obligatory and every individual or legal person shall obey them". On the other hand, in reference to constitutional complaints, Article 77 states: "(1) When the constitutional complaint is accepted and the disputed act repealed, the Constitutional Court shall state in the reasons for the decision which constitutional right has been violated and what makes the violation. (2) When passing the new act from Article 76, paragraph 2, of this Constitutional Act, the competent judicial or administrative body, body of a unit of local and regional self-government, or legal person with public authority, is obliged to obey the legal opinion of the Constitutional Court expressed in the decision repealing the act whereby the applicant's constitutional right was violated." This particular fact has significant relevance for already observed practice of some of the Croatian lower courts which have been approaching similar cases differently. For instance, in the Šimunić case and yet another case in which the lower court came to a completely different conclusion in similar circumstances (Cvijanović, 2016: 104-105).

${ }^{30}$ See the Miljak and Hajduković cases. It must also be noticed that in those two cases the Constitutional Court technically reviewed the situation primarily from the point of view of either Article 29 (right to court) or Article 26 (freedom and privacy of correspondence). However, the "balancing" concerns in those two cases are also visible, either in references to the lower court's argumentation or in its own reasoning.

${ }^{31}$ Note here also that the general standpoints of the Constitutional Court in the April $10^{\text {th }}$ Street case were exclusively addressing the character of the Independent State of Croatia as a negation of basic values of the Republic of Croatia. 
by law. Thirdly, as it emerges from the Miljak and Šimunić cases, the use of certain symbols in the public sphere, which amounts either to incitement to intolerance or hate towards others, is also subject to constitutional rules requiring prescription of the prohibition by law, pursuance of a legitimate aim for restriction and the proportionality principle. Furthermore, public interests aiming at restrictions in that sense may well include not only the respect for dignity of others, but also the prohibition of "unacceptable political messages on which the Republic of Croatia, as an independent, sovereign and democratic state, is not based" and prohibition of expression directed against "basic values of a democratic society". In that sense, both the content and the context of the contested speech are taken into account. In specific cases the presence of others, and not only of those participating at certain events, might be presumed, if, for instance, the events were organized in an unlimitedly open public space that is permanently accessible to an unlimited number of persons. Generally speaking, thus, it seems that the Court in that particular context has not adopted a kind of constitutional review approach akin to the "clear and present" danger test. ${ }^{32}$ And fourthly, the decision in the April $10^{\text {th }}$ Street case marked the crucial switch in the approach of the Court, as it concerns the application of total "exclusion" from the constitutional protection rule. Instead of using the balancing method, the Court proceeded to a straightforward and complete ban, arguing in principle that any attack to the very identity of the Croatian constitutional state may not survive its judicial scrutiny. The said case is therefore quite comparable to the Strasbourg Court rulings related to the application of Article 17 of the European Convention on Human Rights.

32 In a quite precise context of comparative constitutional law related to freedom of speech, similar problems may be found in debates concerning which particular standard of constitutional review is the appropriate one for curbing expression. As summarized by Zechariah Chafee: "The real issue in every free speech controversy is this: whether the state can punish all words which have some tendency, however remote, to bring about acts in violation of law, or only words which directly incite to acts in violation of law" (Strossen, 2018: xix). This particular division in approaches to limits of freedom of expression produced an extremely rich debate, especially in the United States. One of the most recent contributions arguing in favor of a restrained role of state in curtailing freedom of expression is offered in the said book by Strossen. For an almost immediate response to it, see for instance: Delgado and Stefancic, 2018. As Nadine Strossen puts it in very concrete constitutional meaning related to the case-law of the United States Supreme Court, the issue in setting the appropriate limits to free speech is about whether to use the "bad tendency" or the "emergency test". In a similar sense, arguing about possible justifications for regulating hate speech, E. Kulenović is discussing the relationship between "direct harm" and "incitement to hate", two categories to which he also adds "erosion of basic political and social values" (Kulenović, 2016: 33-49). 


\section{The Strasbourg Signals Reconsidered - The Balancing Method or an Outright Ban?}

I would now like to turn to some observations regarding relevant international legal standards as they were interpreted and applied in the case-law of the European Court of Human Rights. A careful observer of the relevant practice of the European Court of Human Rights may easily notice that this particular institution approaches the cases of hate speech in a twofold manner: either through the application of the balancing (or proportionality) method or by excluding the problematic expression from conventional protection in total. These two approaches, as already noted, are reflected in the wording of either the limitation clause of Article 10 par. 2 or in the general norm of Article 17 of the European Convention on Human Rights. ${ }^{33}$ On one side, Article 10 par. 2. of the Convention (Freedom of Expression) states the following: "The exercise of these freedoms, since it carries with it duties and responsibilities, may be subject to such formalities, conditions, restrictions or penalties as are prescribed by law and are necessary in a democratic society, in the interests of national security, territorial integrity or public safety, for the prevention of disorder or crime, for the protection of health or morals, for the protection of the reputation or rights of others, for preventing the disclosure of information received in confidence, or for maintaining the authority and impartiality of the judiciary." On the other side, its Article 17 (Prohibition of Abuse of Rights) prescribes this: "Nothing in this Convention may be interpreted as implying for any State, group or person any right to engage in any activity or perform any act aimed at the destruction of any of the rights and freedoms set forth herein or at their limitation to a greater extent than is provided for in the Convention." ${ }^{34}$

${ }^{33}$ For a short but quite comprehensive overview of the case-law of the European Court of Human Rights in the hate speech cases, which I also used as a source in this paper, see: Hate Speech, European Court of Human Rights (March 2018). Available at: https:/www.echr.coe.int/Documents/ FS_Hate_speech_ENG.pdf, April $16^{\text {th }} 2018$. For additional reviews of the European Court's caselaw in that sense, see also: Oetheimer, 2009; Keane, 2007; Gardašević, 2016; Vasiljević, 2016.

${ }^{34}$ For the European Convention on Human Rights, see: https://www.echr.coe.int/Documents/ Convention_ENG.pdf, October $12^{\text {th }} 2018$.

In that sense, Yutaka Arai explains that the European Court of Human Rights' case-law "reveals a variety of values which have been considered contrary to the 'constitutional paradigm' of the Convention" and specifies that the Court has to that point addressed not only the "typical examples of (neo)-Nazism, fascism, racism, anti-Semitism and (Stalinist) communism", but also additional "variations of expression linked to Islamic 'fundamentalism' and to aggressive forms of Kurdish nationalism" (Arai, 2014: 621-622). It must be noticed, however, that the formulation of Article 17 of the European Convention extends to prohibitions related to both private persons and states themselves, which makes it significantly different from other conventional provisions (Omejec, 2014: 1035-1036). In my paper, I focus only on the cases including the free expression guarantees of private persons. 
The balancing method in the context of free expression was most famously formulated already back in 1976 in the case of Handyside v. the United Kingdom, in which the European Court set the following formula: "Freedom of expression constitutes one of the essential foundations of (a democratic - note: Đ. G.) society, one of the basic conditions for its progress and for the development of every man. Subject to paragraph 2 of Article 10 (of the European Convention - note: Đ. G.), it is applicable not only to 'information' or 'ideas' that are favorably received or regarded as inoffensive or as a matter of indifference, but also to those that offend, shock or disturb the State or any sector of the population. Such are the demands of that pluralism, tolerance and broadmindedness without which there is no 'democratic society'. This means, amongst other things, that every 'formality', 'condition', 'restriction' or 'penalty' imposed in this sphere must be proportionate to the legitimate aim pursued." 35

In fact, the balancing method has indeed been the approach that the European Court used in two freedom of expression cases that might also be relevant for the Croatian context and particular problems it poses itself.

It was already back in 2000 that the Hungarian Constitutional Court upheld the constitutionality of the Hungarian Criminal Code in its Section 269/B that made it unlawful to distribute, use in front of a large public gathering or exhibit in public certain symbols that were defined as "symbols of despotism", including the swastika, the SS sign, the arrow-cross, the hammer and sickle, the five-pointed red star or a symbol depicting the above. The Constitutional Court's reasoning was that the general ban was justified because it was only ten years since Hungary had begun its transition to democracy and the measure was aimed to protect not only public order, but also public peace in cases in which an act would infringe the dignity of a community determined by democratic values. ${ }^{36}$

In the Vajnai case, the applicant, Vice-President of the officially registered Hungarian Workers' Party, was convicted in domestic courts of the offence of using a totalitarian symbol. In fact, during a lawful demonstration where he was

35 Handyside v. the United Kingdom, the European Court of Human Rights (1976), par. 49. See also the case of Erbakan v. Turkey, in which the European Court postulated this: “... Tolerance and respect for the equal dignity of all human beings constitute the foundations of a democratic, pluralistic society. That being so, as a matter of principle it may be considered necessary in certain democratic societies to sanction or even prevent all forms of expression which spread, incite, promote or justify hatred based on intolerance..., provided that any 'formalities', 'conditions', 'restrictions' or 'penalties' imposed are proportionate to the legitimate aim pursued" (Erbakan v. Turkey, the European Court of Human Rights, 2006, par. 56).

${ }^{36}$ Decision of the Constitutional Court of Hungary, 4/2000. Available at: https://hunconcourt. hu/uploads/sites/3/2017/11/en_0014_2000.pdf, October $17^{\text {th }} 2018$. 
a speaker he wore a five-pointed red star on his jacket. The European Court first noted that criminal sanction imposed upon the applicant did present an interference with his freedom of expression, that it was "prescribed by law" and that it pursued the legitimate aims of the state in preventing disorder and protecting the rights of others. In further elaboration of general principles to be applied in the case, the Court highlighted that the test of "necessity in a democratic society" required proof of a "pressing social need" in curbing the contested expression, that "the reasons adduced by the national authorities to justify the interference were "relevant and sufficient" and that the "measure taken was "proportionate to the legitimate aims pursued". ${ }^{37}$ The Court also stated that exceptions to the freedom of speech "must be narrowly interpreted", that "the necessity for any restrictions must be convincingly established" and that "there is little scope under Article 10 par. 2 of the Convention for restrictions on political speech or on debate of questions of public interest". ${ }^{38}$

In applying those principles to the actual case, the Court listed several important arguments to conclude that there was a breach of the freedom of expression. In historical terms, it emphasized that two decades after the fall of communism and transition to pluralism in Hungary had already passed and that the state has proved to be a stable democracy, that it became a member of the European Union and that it fully integrated into the value system of the Council of Europe and the Convention. Consequently, there was no real and present danger of restoring the communist dictatorship. Further, in reference to the "pressing social need" element, required in cases of limitations upon political speech such as in the one under review, the Court posited that symbols with multiple meanings deserved particular attention and that any blanket ban on them actually has a chilling effect. This, in other words, meant that it could lead to restrictions of their use in contexts where it would not be justified. ${ }^{39}$ The Court took account of the fact that "well-known mass violations of

37 Vajnai v. Hungary, the European Court of Human Rights (2008), par. 43 and par. 45. For an overview of the case, see also: Report of Judgment and Decisions/Recueil des arrêts et décisions 2008-IV, the European Court of Human Rights (December 31 ${ }^{\text {st }} 2008$ ), pp. 173-221. Available at: https://www.echr.coe.int/sites/search_eng/pages/search.aspx\#\{\%22fulltext\%22:[\%22applica tionnumber: $\mid \% 2233629 / 06 \backslash \% 22 \% 22], \% 22$ subcategory\%22:[\%22e-reports\%22]\}, October $16^{\text {th }}$ 2018.

38 Ibid., par. 46-47.

39 Barendt addresses this particular issue in the context of the "slippery slope" problem: “... once racist and other forms of hate are proscribed, it will be difficult to resist the extension of the criminal law to ban the dissemination of, say, radical anarchist or socialist ideas. Defenders of hate speech laws argue that they are needed to preserve community relations and in the long term to prevent a break-down in law and order. But these arguments are difficult to accept. They are incompatible with general perspectives underlying arguments for free expression, that it is better 
human rights committed under communism discredited the symbolic value of the red star", but it added that the symbol had multiple meanings. ${ }^{40}$ As such, it could not exclusively be linked to communism in its totalitarian form, but should rather be seen also as the symbol of the international workers' movement struggling for a fairer society, as well as the symbol of some lawful political parties active in several member states of the Council of Europe. Moreover, the Court found that the applicant acted in a lawfully organized and peaceful demonstration, that he was present there as the vice-president of a registered political party and that it was not known that he had any intention of participating in Hungarian political life in defiance of the rule of law. Therefore, the blanket ban of the symbol was not acceptable. For the purposes of evaluating the aim of the state to prevent disorder, the Court pointed that the Government "have not referred to any instance where an actual or even remote danger of disorder triggered by the public display of the red star had arisen in Hungary", that "the containment of a mere speculative danger, as a preventive measure for the protection democracy, cannot be seen as a 'pressing social need'", and that in any case in Hungarian law there existed less intrusive measures for suppressing possible public disturbances in such cases. ${ }^{41}$ Finally, in reference to the objective of protection of the rights of others, the Court accepted that the public display of the symbol could "create uneasiness among past victims and their relatives, who may rightly find such displays disrespectful". ${ }^{42}$ It, however, clarified that "such sentiments, however understandable, cannot alone set the limits of freedom of expression" and that "given the well-known assurances which the Republic of Hungary provided legally, morally and materially to the victims of communism, such emotions cannot be regarded as rational fears". ${ }^{43}$ To this point, the Court's general view was probably most clearly stated in the following: "In the Court's view, a legal system which applies restrictions on human rights in order to satisfy the dictates of public feeling - real or imaginary - cannot be regarded as meeting the pressing social needs recognized in a democratic society, since that society must remain reasonable in its judgment. To hold otherwise would mean that freedom of speech and opinion is subjected to the heckler's veto." ${ }^{44}$ It is also worth mentioning

for a society to debate its underlying tensions and that the state infringes the freedom if it outlaws the dissemination of ideas which the majority dislikes or which are offensive, even insulting, to particular communities" (Barendt, 2012: 903-904). For the same argument in defense from the "slippery slope" problem, see: Arai, 2014.

${ }^{40}$ Vajnai v. Hungary, the European Court of Human Rights (2008), par. 52.

${ }^{41}$ Ibid., par. 55.

${ }^{42}$ Ibid., par. 57.

${ }^{43}$ Ibid.

${ }^{44}$ Ibid. 
that, following the decision in the Vajnai case, the Hungarian Constitutional Court in 2013 struck down the above-mentioned Section 269/B of the Criminal Code on the grounds that it was formulated too widely, that it violated the requirement of legal certainty and that it disproportionately restricted the freedom of expression, without taking into account the motive of the act and the context and consequences of using the symbols enumerated in the provision. ${ }^{45}$

On the other hand, in the case of Fáber v. Hungary, ${ }^{46}$ the European Court was called upon to decide whether the public display of the Hungarian Árpád flag close to the site where a demonstration against racism and hatred organized by the Hungarian Socialist Party (MSZP) was taking place could justify detention and fining of the applicant. The applicant was silently holding the said flag on a location where in the Second World War mass exterminations of Jews were committed. After warned by the police that he should either remove the banner or leave, he refused and was subsequently put in custody and fined for the regulatory offence of disobeying police instructions. The appeal court held that his conduct "had been of a provocative nature, likely to result in unruliness in the context of the ongoing Socialist demonstration, and that his right to free expression could not be considered as reaching so far as to cause prejudice to public order" ${ }^{47}$ Here the European Court had to review the case from both the freedom of assembly (Article 11 of the Convention) and the freedom of expression (Article 10) perspectives, and it thus combined general principles it had construed in its case-law as related to both provisions. In relation to the former provision of the European Convention, the Court's general standards required that "the guarantees of Article 11 of the Convention apply to all assemblies except those where the organizers and participants have violent intentions or otherwise deny the foundations of a "democratic society"". ${ }^{48}$ Additionally, the Court stressed that "the mere existence of a risk is insufficient for banning the event: in making their assessment the authorities must produce concrete estimates of the potential scale of disturbance in order to evaluate the resources necessary for neutralizing the threat of violent clashes" ${ }^{49}$ Allowing that in cases of collision of compe-

${ }^{45}$ Decision of the Constitutional Court of Hungary, 4/2013. CODICES summary of the Decision available at: http://www.codices.coe.int/NXT/gateway.dll/CODICES/precis/eng/eur/hun/ hun-2013-1-003?fn=document-frameset.htm\& $\mathrm{f}=$ templates $\$ \mathrm{q}=\$ \mathrm{uq}=\$ \mathrm{x}=\$ \mathrm{up}=1$ force $=654$, October $17^{\text {th }}$ 2018. For another approach taking into account requirements of legal specificity of criminal law provisions regulating the use of totalitarian symbols, see: Judgment of the Constitutional Tribunal of Poland K11/10 (2011), available at: http://trybunal.gov.pl/fileadmin/content/ omowienia/K_11_10_EN.pdf, October 17 2018.

${ }^{46}$ Fáber v. Hungary, the European Court of Human Rights (2012).

${ }^{47}$ Ibid., par. 7.

48 Ibid., par. 37.

49 Ibid., par. 40. 
ting fundamental rights the states had a certain wide discretion to evaluate security risks, the Court proceeded to establish that such wide discretion was justified only "where the existence of a serious threat of a violent counter-demonstration is convincingly demonstrated". ${ }^{50}$ And in the instant case such a serious or clear threat or present danger of violence was not found because "neither the applicant's conduct nor that of the others present was threatening or abusive, and it was only the holding of the flag that was considered provocative". ${ }^{51}$ The Court actually said that "given the applicant's passive conduct, the distance from the MSZP demonstration and the absence of any demonstrated risk of insecurity or disturbance", the interference in his freedom of assembly was not justified, even though some of the demonstrators might have found the presence of the contested flag provocative. ${ }^{52}$

In the strict sense of the freedom of expression issue, the Court opened its argument by saying that symbols which had multiple meanings and were used in political speech deserved "careful examination of the context" before "one can draw a meaningful distinction between shocking and offensive language which is protected by Article 10 and that which forfeits its right to tolerance in a democratic society". ${ }^{53}$ Taking that "the expressive nature of the display of an object depends on the circumstances of the situation" the Court added that "the applicant's decision to display that flag in the vicinity of the MSZP demonstration must be regarded as his way of expressing - by way of a symbol - his political views, namely a disagreement with the ideas of the MSZP demonstrators". ${ }^{54}$ Moreover, since no "demonstrated risk of insecurity or disturbance" was found, the "pressing social need" for the police to intervene could not be established..$^{55}$ This led the Court to further examine whether, however, it was possible to conclude that the display of the banner in itself "was capable of causing public disorder" or whether it "required the intervention of the police" on other grounds based upon paragraph 2 of Article 10 of the Convention. ${ }^{56}$

Assuming here the multiple-meanings quality of the flag, taken "both as a historical symbol and as a symbol reminiscent of the Arrow Cross regime", the Court then passed on to see whether "the display could have created a pressing social need

50 Ibid., par. 42-43. In that particular sense, this case concerned the collision between the freedom of expression and assembly of the applicant on one side and the demonstrators' right to protection against disruption of their assembly on the other.

51 Ibid., par. 46.

52 Ibid., par. 45 and par. 47. For an overview of the Strasbourg case-law related to the freedom of assembly, among other sources, see: Gardašević, 2011.

53 Fáber v. Hungary, the European Court of Human Rights (2012), par. 36 and par. 54.

54 Ibid., par. 52.

55 Ibid., par. 53.

56 Ibid. 
to restrict the use of the symbol, for the protection of the rights of others" and stressed that "in the interpretation of the meaning of an expression, for the determination of the proportionality of a specific restrictive measure, the location and the timing of the display of a symbol or of other expressions with multiple meanings play an important role". ${ }^{57}$ Applying then the "location" and the "timing" elements to the actual case, it concluded that there existed no pressing social need for the restriction since the mere display of the banner was "neither intimidating, nor capable of inciting to violence by instilling a deep-seated and irrational hatred against identifiable persons". ${ }^{58}$ The Court also added that "ill feelings or even outrage, in the absence of intimidation, cannot represent a pressing social need for the purposes of Article 10 par. 2, especially in view of the fact that the flag in question has never been outlawed". ${ }^{9}$

Nevertheless, the final part of the Court's opinion in this case presented some general additional observations as well. Those observations merit particular attention and deserve to be quoted in total. The Court actually stated the following: "The Court does not exclude that the display of a contextually ambiguous symbol at the specific site of mass murders may in certain circumstances express identification with the perpetrators of those crimes; it is for this reason that even otherwise protected expression is not equally permissible in all places and at all times. In certain countries with a traumatic historical experience comparable to that of Hungary, a ban on demonstrations - to be held on a specific day of remembrance - which are offensive to the memory of the victims of totalitarianism who perished at a given site may be considered to represent a pressing social need. The need to protect the rights to honour the murdered and the piety rights of their relatives may necessitate an interference with the right to freedom of expression, and it might be legitimate when the particular place and time of the otherwise protected expression unequivocally changes the meaning of a certain display. Similar considerations apply if the expression, because of its timing and place, amounts to the glorification of war crimes, crimes against humanity or genocide (see Garaudy v. France...). Moreover, where the applicant expresses contempt for the victims of a totalitarian regime as such, this may amount - in application of Article 17 of the Convention - to an abuse of Convention rights (see Witzsch v. Germany...)." ${ }^{\prime 60}$

${ }^{57}$ Ibid., par. 55.

58 Ibid., par. 56.

${ }^{59}$ Ibid.

${ }^{60}$ Ibid., par. 58. See also: Hate Speech, European Court of Human Rights (March 2018) (op. cit.), p. 8. For other possibly relevant cases of the European Court in terms of the balancing method in this context, apart from the decisions in Fáber v. Hungary and Vajnai v. Hungary, see also: Leroy v. France, the European Court of Human Rights (2008), and Féret v. Belgium, the European Court of Human Rights (2009). 
On the other hand, the European Court has in its practice also been applying the second approach, the one leading to an outright exclusion of conventional protection and embedded in Article 17 of the Convention. In this particular context, however, the European Court has set much higher thresholds to be attained in order to trigger the specific exclusion rule. ${ }^{61}$ It was thus decided that the Convention does not protect those applicants who, either in a series of articles or in a book, aim to spread ethnic hate towards a particular group or promote negationism and revisionism. ${ }^{62}$ The same was concluded in a case involving possession of leaflets addressed to the "White Dutch people", which tended to make sure that everyone who was not white left the Netherlands. ${ }^{63}$ In Norwood v. the United Kingdom, ${ }^{64}$ the European Court upheld the conviction for aggravated hostility towards a religious group of a person who displayed in his window a poster representing the Twin Towers in flame, with the accompanying words: "Islam out of Britain - Protect the British People". The European Court decided that the words and images on the poster had amounted to a public expression of attack on all Muslims in the UK and that such a general and vehement attack on a religious group, linking the group as a whole with a grave act of terrorism, was incompatible with the values proclaimed and guaranteed by the Convention. ${ }^{65}$

It may also be noticed that Article 17 of the European Convention was invoked by the government in the previously mentioned Vajnai v. Hungary case. However, having distinguished the circumstances of that particular case from the case-law that the government relied upon, ${ }^{66}$ the European Court stressed several points: that here it was neither that the justification of Nazi-like politics was at stake nor that the freedom of expression was intended to be used by groups with totalitarian motives; that it was not argued by the government "that the applicant expressed contempt for

${ }^{61}$ In that sense, D. Keane (2007: 642) is stressing that "the Court has a higher standard of protection against Holocaust denial and related questioning of the historical facts of World War II, which it will attack directly under Article 17 of the European Convention on Human Rights (ECHR), than other forms of racist or hate speech, which are examined under Article 10".

${ }^{62}$ See: Pavel Ivanov v. Russia, the European Court of Human Rights (2007); Garaudy v. France, the European Court of Human Rights (2003).

63 Glimmerveen and Haqenbeek v. the Netherlands, the European Commission of Human Rights (1979).

64 Norwood v. the United Kingdom, the European Court of Human Rights (2004).

${ }^{65} \mathrm{Ibid}$. For an overview of the case, see also: Report of Judgment and Decisions/Recueil des arrêts et décisions 2004-XI, the European Court of Human Rights (December $31^{\text {st }} 2004$ ), pp. 173-221. Available at: https://www.echr.coe.int/Documents/Reports_Recueil_2004-XI.pdf, October $17^{\text {th }} 2018$.

${ }^{66}$ The government, among other cases, pointed in this respect to Garaudy v. France, the European Court of Human Rights (2006), and Lehideux and Isorni v. France, the European Court of Human Rights (1998). 
the victims of a totalitarian regime or belonged to a group with totalitarian ambitions"; and that it cannot be concluded that the display of the symbol was intended to justify or propagate totalitarian oppression serving "totalitarian groups". The applicant was, according to the Court, rather wearing a symbol of lawful left-wing political movements. Therefore, the Article 17 claim failed. ${ }^{67}$

Finally, although the Sugg and Dobbs v. Sweden case ${ }^{68}$ was not really an example of application of Article 17 of the Convention, it deserves special mention here. A good reason for it is that the case is directly relevant for possible further rethinking of the guidelines set up, for instance, in the Vajnai v. Hungary and Fáber v. Hungary cases. In Sugg and Dobbs national courts convicted the applicants because they had raised their hands in the air during a rock concert, thus imitating the socalled "Hitler salutes", and had been shouting the words "Sieg heil". The European Court found that the conduct of the applicants was well qualified by the national court as constituting an offence under the Swedish law. In its reasoning it stressed that, in applying the relevant provision of the Penal Code to the case, the national Court of Appeals "... had regard to the travaux préparatoires to that provision and to a judgment by the Supreme Court of 17 October 1996 concerning the use of Nazi symbols and concluded that the 'Hitler salute' and the words 'Sieg heil' were clear manifestations of Nazism and racist ideology and expressed contempt for other persons on account of their race or colour". ${ }^{69}$

\section{Conclusion}

As I said at the outset, my primary concern in this paper was to examine which specific types of speech may be covered by constitutional free expression guarantees, and be therefore treated as the case of balancing process between them and some opposed public and private interests, and which should be subjected to a complete ban. I hope that in the foregoing text I have managed to show what I believe are the relevant elements for a more detailed understanding of that particular problem both in the Croatian and in the European contexts. For this purpose, I have drawn some elements of the analysis as they stem from two high judicial authorities, the Croatian Constitutional Court and the European Court of Human Rights. However, there still remain some additional observations I think might be relevant for a possible more comprehensive approach to future constitutional interpretation in the Croatian settings.

Undoubtedly, the review of the relevant case-law which I have presented earlier does not cover all the examples which fall under the exclusion rule, as it is

${ }^{67}$ Vajnai v. Hungary, the European Court of Human Rights (2008), par. 20-26.

${ }^{68}$ Sugg and Dobbs v. Sweden, the European Court of Human Rights (2001).

${ }^{69}$ Ibid. 
presented in Article 17 of the European Convention. ${ }^{70}$ The list thereof is far more extensive and in my paper I just focused on those cases of both high instances that may have relevance for the freedom of expression as it refers to the use of symbols with some contested meanings. Additionally, and that goes particularly for the Strasbourg case-law, much of what I have shown is often seen merely in the context of "hate speech". However, this seems to be just one part of the problem.

In that respect, it must be added that the specific issue of the public use of contested symbols exceeds strict boundaries of the hate speech problem as such and enters into some other particular constitutional contexts that also deserve attention. More precisely, similar constitutional philosophy may be observed in those approaches which forbid the activities that aim at destroying certain core values or principles upon which constitutional and public orders are based. Generally speaking, this is exactly the field of values having fundamental meaning for the overall construction of a constitutional document. Once again, the best example of that approach is seen in the wording of Article 17 of the European Convention on Human Rights, but the list of relevant references thereof includes also other legal sources, such as, for instance, the Charter of Fundamental Rights of the European Union, ${ }^{71}$ or various constitutional texts. ${ }^{72}$ In purely theoretical terms, the same concerns might

${ }^{70}$ For a comprehensive list of the European Court of Human Rights' cases dealing with the problem of hate speech, both those including the application of Article 14 and those including Article 17 of the European Convention, see: Hate Speech, European Court of Human Rights (March 2018).

71 See Article 54 of the Charter of Fundamental Rights of the European Union (Prohibition of Abuse of Rights). For the text of the Charter of Fundamental Rights of the European Union see: https://eur-lex.europa.eu/legal-content/EN/TXT/PDF/?uri=OJ:C:2016:202:FULL\&from=EN, October $12^{\text {th }} 2018$.

${ }^{72}$ For instance, in the German Basic Law of 1949 the freedom of expression, as well as its general limitations, are defined in Article 5. On the other hand, Article 18 of the Basic Law (Forfeiture of Basic Rights) posits the following: "Whoever abuses the freedom of expression, in particular the freedom of the press (paragraph (1) of Article 5), the freedom of teaching (paragraph (3) of Article 5), the freedom of assembly (Article 8), the freedom of association (Article 9), the privacy of correspondence, posts and telecommunications (Article 10), the rights of property (Article 14), or the right of asylum (Article 16a) in order to combat the free democratic basic order shall forfeit these basic rights. This forfeiture and its extent shall be declared by the Federal Constitutional Court." See: https:/www.constituteproject.org/constitution/German_Federal_ Republic_2014?lang=en, October $12^{\text {th }} 2018$. See also Article 25 par. 3 of the Greek Constitution which states: "The abusive exercise of rights is not permitted." On different meanings of Article 17 of the European Convention and Article 54 of the Charter on one side (being seen as interpretative norms which makes their application possible in relation to all other rights in the said documents) and Article 18 of the German Basic Law (understood as a structural norm linked to rather specific, enumerated rights), see: Mock and Demuro, 2010. 
be traced well back to Karl Loewenstein's classical text on militant democracy and fundamental rights (Loewenstein, 1937a; 1937b). ${ }^{73}$

It seems that this is quite close to the point of discussion which the Croatian Constitutional Court has already reached in its overall discourse on the concepts of "the basic values of a democratic society"74 on one hand and "the structural principles" upon which "the very structure and essence of the Croatian state" or its "constitutional identity" are founded on the other. ${ }^{75}$ I must stress that the "constitutional identity" concept as such is not an entire novelty in Croatian constitutional law. For some time now, it has attracted the attention of both the Constitutional Court itself and several domestic scholars. ${ }^{76}$ What is of utmost significance here is the fact that the Croatian Constitutional Court used the concept as one of the central benchmarks of review in the April $10^{\text {th }}$ Street case.

Yet another element taken as relevant by the Court in the same case was the application of the Preamble to the Croatian Constitution..$^{77}$ Although, comparatively speaking, there might be some differences in views about possible "incorporation" of preambles into constitutional texts for specific purposes of invoking their word-

${ }^{73}$ In that particular sense, H. Cvijanović puts the American and the European approaches to curbing of hate speech in opposition and stresses that K. Lowenstein, "who influenced the creation of the speech space in Europe after the Second World War", took that "the militant democracy stems from the perception on weakness of the European democratic institutions which itself was used by fascist movements" and thus "argued in favor of repressive measures against antidemocratic movements as the defense of the European democracy" (Cvijanović, 2016: 80). For other sources relevant for a general overview of the "militant democracy" concept, see also: Sajó, 2014; Gardašević, 2014; Smerdel, 2013; Kostadinov, 2011.

${ }^{74}$ The Šimunić case.

75 The April $10^{\text {th }}$ Street case.

${ }^{76}$ For a broader view on the concept of "constitutional identity" in the Croatian constitutional doctrine, see also: Smerdel, 2013; 2014; Kostadinov, 2011; Gardašević, 2014; Toplak and Gardašević, 2017; Rodin, 2012; Horvat Vuković, 2014; Podolnjak and Smerdel, 2014. For distinctive foreign perspectives on the concept of constitutional identity, see also: Rosenfeld, 2010; Jacobsohn, 2010.

${ }^{77}$ It is worth repeating here what the Constitutional Court actually stated in this particular sense: "Starting with what was already said, neither the Constitution nor the Convention can provide any protection to the celebration of April $10^{\text {th }} 1941$, the date of the establishment of the Independent State of Croatia, in any way, including the cases in which names of streets and squares are given in memory of that date. In fact, the 'well-known historical truth' is that the Independent State of Croatia was a Nazi and a fascist creation and as such it represented the absolute negation of legitimate aspirations of the Croatian people to found its own state, as well as grave historical abuse of such aspirations. Therefore, according to the Preamble of the Constitution, the Republic of Croatia is not a successor to the Independent State of Croatia on any basis." See: the April $10^{\text {th }}$ Street case. 
ing in resolving the actual cases ${ }^{78}$ it is also a fact that the Croatian Constitutional Court has accepted the positive answer to that point. In other words, in our constitutional setting, the Preamble of the Constitution is indeed taken as a valid resource of references. And even more importantly, the Preamble, although not in its entirety, has already been made part of the "constitutional identity" concept. ${ }^{79}$

Therefore, the central question for future analyses is this: how can one possibly read the Preamble of the Croatian Constitution in the specific context of the public use of contested symbols? Some critical answers to that question have already been offered. ${ }^{80}$ In an attempt to present more material for prospective discussions and a more comprehensive approach to constitutional interpretation, I will now just briefly offer some of my personal views.

From the point of view of contested symbols or disputed insignia, as it reveals itself in the Croatian context, it seems that by far the most relevant references are found in those parts of the Preamble which mention the regimes that either had already existed or started to exist during the Second World War. That an inevitable need for strict distinctions thereof is, however, indispensable, may be argued from at least two important points. The first one is intrinsically linked to both the literal and the more strictly "constitutional" reading of the text of the Preamble. In that particular sense, it does not only matter which literal constitutional prescriptions the Preamble uses in terms of the particular views it takes towards the past. ${ }^{81}$ It is also

${ }^{78}$ For the views opposing the conclusion that the Preamble to the Constitution of the United States may have direct relevance, see both the standings of the United States Supreme Court in Jacobson v. Massachusetts, 197 U.S. 11, 22 (1905), and the words of Joseph Story who argued: "The preamble never can be resorted to, to enlarge the powers confided to the general government, or any of its departments. It cannot confer any power per se; it can never amount, by implication, to an enlargement of any power expressly given. It can never be the legitimate source of any implied power, when otherwise withdrawn from the constitution" (Story, 1833: 164). On the other hand, the French approach in interpreting constitutional preambles is somewhat different. The Preamble to the 1946 French Constitution is now taken as part of the so-called "block of constitutionality", meaning that it has an equal value to other constitutional sources that may serve as grounds for reviewing the constitutionality of laws. In other words, the 1946 Preamble is not merely a declaratory text.

79 Decision of the Constitutional Court of the Republic of Croatia, U-I-3597/2010, July $29^{\text {th }}$ 2011, par. 30.1. In that Decision, however, the Court "incorporated" only that part of the Preamble which refers to the concept of national sovereignty and to the equal protection of national minorities. It is therefore of utmost significance to see whether other parts of the Preamble will in future also be thus incorporated. This undoubtedly bears significant meaning for the discourse on the public use of contested symbols as well.

${ }^{80}$ See the separate opinion of judge M. Šumanović in the April $10^{\text {th }}$ Street case.

${ }^{81}$ In fact, specifying those historical events which laid foundations for the re-establishment of the Croatian state and national sovereignty in 1990, the Preamble among other things clearly 
important to note that significant differences thereof also exist in the context of how the inheritance of that past was once overcome in the strict meaning of the constitutional procedure thus undertaken. ${ }^{82}$

The second, and my final point here is that some rather important lessons should be drawn from the relevant case-law of the European Court of Human Rights. As I have already shown, that Court has quite firmly established the criteria upon which some contested symbols of the past may be evaluated. The relevant reasoning thereof, for the purposes of understanding the European perspective, pertains to three distinguishable types of symbols. The first category includes the symbols which may not be denied conventional protection, unless directly provoking some tangible harm that fulfills the requirement of the "pressing social need" for restrictions. Those symbols are also distinctive as to their position in the overall international context. The second category is related to the symbols that are similar to the first ones, but are at the same time devoid of any other internationally recognized meaning that would provide an additional presumption in terms of their constitutional validity. And the third category is reserved for symbols with an outright and purely unambiguous meaning.

Needless to say, the European Court of Human Rights' material relevant for further analyses in that context includes, in that particular order, the decisions in Vajnai v. Hungary, Fáber v. Hungary and Sugg and Dobbs v. Sweden cases.

points to the decisions of the Antifascist Council of National Liberation of Croatia (1943), as well as to the subsequent Constitution of the People's Republic of Croatia (1947) and all later constitutions of the Socialist Republic of Croatia (1963-1990). Contrary to that, the proclamation of the Independent State of Croatia (1941) is explicitly rejected as any possible constitutional reference thereof. In a comparable, but rather broader context of historical experiences of different states, Barendt argues: “... each country has a distinct historical experience of the dangers of hate speech. On that basis it is understandable that after the apartheid regime the framers of the South African Constitution decided wholly to exclude hate speech from the free expression guarantee. Equally, Holocaust denial laws make sense in countries which have recently experienced Nazi and other anti-Semitic regimes or in which there is good reason to believe that, left unchecked, the fabrications of revisionist historians will be widely accepted. But with the passage of time, it would surely be wrong for the state to determine historical truth; a law banning the publication of 'revisionist' histories of the atrocities committed by religious communities, say, during the Crusades or the Thirty Years War, would infringe freedom of expression, however insulting these accounts are to their members now" (Barendt, 2012: 904).

82 To that particular point, it does matter to see whether certain past regimes were explicitly rejected as having any constitutional reference at all or they were replaced by new ones through properly conducted constitutional processes. Even more precisely, the 1990 Constitution of the Republic of Croatia was enacted through a regular and legally prescribed constitution-making procedure. 


\section{REFERENCES}

Arai, Yutaka. 2014. Article 10: Freedom of Expression, in: Harris, D., O'Boyle, M., Bates, E. and Buckley, C. M. (eds.): Law of the European Convention on Human Rights ( $3^{\text {rd }}$ Edition). Oxford University Press. Oxford: 613-709.

Barendt, Eric. 2012. Freedom of Expression, in: Rosenfeld, M. and Sajó, A. (eds.): The Oxford Handbook of Comparative Constitutional Law. Oxford University Press. Oxford: 891-908.

Cvijanović, Hrvoje. 2016. Govor kao verbalni i simbolički prostor slobode i političkog: američki poučak i govor mržnje u EU i Hrvatskoj, in: Kulenović, E. (ed.): Govor mržnje u Hrvatskoj. Fakultet političkih znanosti Sveučilišta u Zagrebu. Zagreb: 61119.

Delgado, Richard and Stefancic, Jean. 2018. Must We Defend Nazis?. New York University Press. New York.

Dialogue Document: Postulates and Recommendations on Specific Normative Regulation of Symbols, Emblems and other Insignia of Totalitarian Regimes and Movements, the Council for Dealing with the Consequences of Undemocratic Regimes, February $28^{\text {th }} 2018$ (Zagreb). The English version at: https://vlada.gov.hr/UserDocsImages//Vijesti/2018/05\%20svibanj/5\%20svibnja//DOKUMENT\%20DIJALOGA\%20ENG.pdf, October $17^{\text {th }} 2018$. The Croatian version at (including the separate opinions) at: https://vlada.gov.hr/istaknute-teme/dokument-dijaloga-temeljna-polazista-i-preporuke-o-posebnom-normativnom-uredjenju-simbola-znakovlja-i-drugih-obiljezja/23424, October $17^{\text {th }} 2018$.

Gardašević, Đorđe. 2011. Sloboda mišljenja, savjesti i vjeroispovijedi te sloboda okupljanja i udruživanja: čl. 9. i čl. 11. Europske konvencije za zaštitu ljudskih prava i temeljnih sloboda, in: Radačić, I. (ed.): Uskladenost hrvatskih zakona i prakse sa standardima Europske konvencije za zaštitu ljudskih prava i temeljnih sloboda. Centar za mirovne studije. Zagreb: 126-151.

Gardašević, Đorđe. 2014a. Neustavni ustavni amandmani i Ustavni sud Republike Hrvatske, in: Bačić, A. (ed.): Konstitucionalizacija demokratske politike. Hrvatska akademija znanosti i umjetnosti. Zagreb: 85-110.

Gardašević, Đorđe. 2014b. Ograničenja ljudskih prava i temeljnih sloboda u izvanrednim stanjima. Hrvatska udruga za ustavno pravo. Zagreb.

Gardašević, Đorđe. 2016. Govor mržnje i hrvatski ustavnopravni okvir, in: Kulenović, E. (ed.): Govor mržnje u Hrvatskoj. Fakultet političkih znanosti Sveučilišta u Zagrebu. Zagreb: 160-161.

Hate Speech, European Court of Human Rights (March 2018). Available at: https://www. echr.coe.int/Documents/FS_Hate_speech_ENG.pdf, April $16^{\text {th }} 2018$.

Horvat Vuković, Ana. 2014. Referendum narodne inicijative 2013. - ustavni identitet kao osnova ustavnosudskog aktivizma, in: Podolnjak, R. and Smerdel, B. (eds.): 
Referendum narodne inicijative u Hrvatskoj i Sloveniji - Ustavnopravno uređenje, iskustva i perspektive. Hrvatska udruga za ustavno pravo. Zagreb: 149-177.

Jacobsohn, Garry J. 2010. Constitutional Identity. Harvard University Press. Cambridge MA.

Keane, David. 2007. Attacking Hate Speech Under Article 17 of the European Convention on Human Rights. Netherlands Quarterly of Human Rights, (25) 4: 641-663.

Kostadinov, Biljana. 2011. Ustavni identitet, in: Bačić, J. (ed.): Dvadeseta obljetnica Ustava Republike Hrvatske. Hrvatska akademija znanosti i umjetnosti. Zagreb: 305-337.

Kulenović, Enes. 2016. Sloboda govora i govor mržnje, in: Kulenović, E. (ed.): Govor mržnje u Hrvatskoj. Fakultet političkih znanosti Sveučilišta u Zagrebu. Zagreb: 3349.

Loewenstein, Karl. 1937a. Militant Democracy and Fundamental Rights I. The American Political Science Review, (31) 3: 417-432.

Loewenstein, Karl. 1937b. Militant Democracy and Fundamental Rights II. The American Political Science Review, (31) 4: 638-658.

Mock, William and Demuro, Gianmario. 2010. Human Rights in Europe - Commentary on the Charter of Fundamental Rights of the European Union. Carolina Academic Press. Durham, North Carolina.

Oetheimer, Mario. 2009. Protecting Freedom of Expression: The Challenge of Hate Speech in the European Court of Human Rights Law. Cardozo Journal of International and Comparative Law, (17) 3: 433-434.

Omejec, Jasna. 2014. Konvencija za zaštitu ljudskih prava i temeljnih sloboda u praksi Europskog suda za ljudska prava (2 ${ }^{\text {nd }}$ ed.). Novi informator. Zagreb.

Podolnjak, Robert and Smerdel, Branko (eds.). 2014. Referendum narodne inicijative u Hrvatskoj i Sloveniji - Ustavnopravno uređenje, iskustva i perspektive. Hrvatska udruga za ustavno pravo. Zagreb.

Report of Judgment and Decisions/Recueil des arrêts et décisions 2004-XI, the European Court of Human Rights (December $31^{\text {st }} 2004$ ).

Report of Judgment and Decisions/Recueil des arrêts et décisions 2008-IV, the European Court of Human Rights (December 31 $1^{\text {st }} 2008$ ).

Rodin, Siniša. 2012. Ustavni protekcionizam i nacionalni identitet, in: Bačić, A. (ed.): Ustavi i demokracija: Strani utjecaji i domaći odgovori. Hrvatska akademija znanosti i umjetnosti. Zagreb: 145-173.

Rose, Hadley. 2014. Speak No Evil, Hear No Evil, Do No Evil: How Rationales for the Criminalization of Hate Speech Apply in Transitional Contexts. Willamette Journal of International Law and Dispute Resolution, (22) 2: 313-341.

Rosenfeld, Michel. 2010. The Identity of the Constitutional Subject: Selfhood, Citizenship, Culture, and Community. Routledge. London, New York. 
Sajó, András (ed.). 2014. Militant Democracy. Eleven International Publishing. Utrecht. Smerdel, Branko. 2013. Ustavno uređenje europske Hrvatske. Narodne novine. Zagreb.

Smerdel, Branko. 2014. In Quest of a Doctrine - Croatian Constitutional Identity in the European Union. Zbornik Pravnog fakulteta u Zagrebu, (64) 4: 514-534.

Story, Joseph. 1833. Commentaries on the Constitution of the United States. Hilliard, Gray and Company and Brown, Shattuck and Co. Boston and Cambridge.

Strossen, Nadine. 2018. Hate - Why We Should Resist it With Free Speech, Not Censorship. Oxford University Press. Oxford.

Toplak, Jurij and Gardašević, Đorđe. 2017. Concepts of National and Constitutional Identity in Croatian Constitutional Law. Review of Central and East European Law, (42) 4: 263-293.

Vasiljević, Snježana. 2016. Diskriminatorni govor i govor mržnje u europskom pravnom okviru, in: Kulenović, E. (ed.): Govor mržnje u Hrvatskoj. Fakultet političkih znanosti Sveučilišta u Zagrebu. Zagreb: 121-150.

Waldron, Jeremy. 2012. The Harm in Hate Speech. Harvard University Press. Boston.

\section{Case-law of the European Court of Human Rights and European Commission for Human Rights (by date)}

Handyside v. the United Kingdom, the European Court of Human Rights (1976).

Glimmerveen and Haqenbeek v. the Netherlands (1979).

Jersild v. Denmark (1994).

Hertel v. Switzerland (1998).

Lehideux and Isorni v. France, the European Court of Human Rights (1998).

Witzsch v. Germany, the European Court of Human Rights (1999).

Sugg and Dobbs v. Sweden, the European Court of Human Rights (2001).

Norwood v. the United Kingdom, the European Court of Human Rights (2004).

Steel and Morris v. the United Kingdom (2005).

Garaudy v. France, the European Court of Human Rights (2006).

Ždanoka v. Latvia, the European Court of Human Rights (2006).

Pavel Ivanov v. Russia, the European Court of Human Rights (2007).

Guja v. Moldova, the European Court of Human Rights (2008).

Leroy v. France, the European Court of Human Rights (2008).

Vajnai v. Hungary, the European Court of Human Rights (2008).

Féret v. Belgium, the European Court of Human Rights (2009).

Fáber v. Hungary, the European Court of Human Rights (2012). 


\section{Case-law of the Croatian Constitutional Court (by date)}

Decision of the Constitutional Court of the Republic of Croatia, U-I-3597/2010 (July $29^{\text {th }}$ 2011).

Decision of the Constitutional Court of the Republic of Croatia, U-VIIR-4640/2014 (August $12^{\text {th }}$ 2014).

Decision of the Constitutional Court of the Republic of Croatia, U-III-1296/2016 (May $25^{\text {th }} 2016$ ).

Decision of the Constitutional Court of the Republic of Croatia, U-III-5226/2013 (October $18^{\text {th }}$ 2016).

Decision of the Constitutional Court of the Republic of Croatia, U-III-2588/2016 (November $8^{\text {th }}$ 2016).

Decision of the Constitutional Court of the Republic of Croatia, U-II-6111/2013 (October 10 2017 ).

\section{Case-law of Other Foreign Courts}

Decision of the Constitutional Court of Hungary, 4/2000.

Decision of the Constitutional Court of Hungary, 4/2013.

Jacobson v. Massachusetts, 197 U.S. 11, 22 (1905).

Judgment of the Constitutional Tribunal of Poland, K11/10 (2011).

Mailing Address: Đorđe Gardašević, University of Zagreb, Law Faculty, Trg Republike Hrvatske 14, 10000 Zagreb.E-mail: dgardase@pravo.hr 